\begin{tabular}{llllllllll}
$\mathbf{P}$ & $\mathbf{R}$ & $\mathbf{A}$ & $\mathbf{W}$ & $\mathbf{O}$ & $\mathbf{K}$ & $\mathbf{A}$ & $\mathbf{R}$ & $\mathbf{N}$ & $\mathbf{E}$ \\
\hline
\end{tabular}

KOŚCIÓŁ I PRAWO 9(22) 2020, nr 1, s. 133-141

DOI: https://doi.org/10.18290/kip2091-8

Wioletta Dudziec-Rzeszowska

\title{
THE SEAL OF CONFESSION IN POLISH CRIMINAL LAW - SUBSTANTIVE AND PROCEDURAL ASPECTS. DE LEGE FERENDA POSTULATES
}

The legal definition of "the seal of confession" has not been regulated by the Polish legislator. The subject literature points out that the seal of holy confession applies when "the given Church or religious association, as part of its internal regulations, provides an institution that serves as a platform for an individual conversation of a unique religious nature between an entity eligible for that purpose (confessor) and a believer (penitent)" [Pieróg $2015,17]$. Solutions employed in order to protect the seal of confession can be found not only in the canon law, but also in provisions of the Polish substantive and procedural criminal law. The legislator in can. 983, para. 1 of the 1983 Code of Canon Law refers to the seal of confession emphasizing its indefeasible character. ${ }^{1}$ Therefore, it must be concluded that the importance of the sacrament of penance has been acknowledged both by the Church and state legislators. Criminal procedure does not establish a new

Wioletta Dudziec-Rzeszowska, M.A. - advocate trainee at the Kuyavian-Pomeranian Bar Association in Toruń; ul. Rynek Staromiejski 17, 87-100 Toruń, Poland; e-mail: dudziec.w@gmail.com; https://orcid.org/0000-0002-3181-9073

${ }^{1}$ Codex Iuris Canonici auctoritate Ioannis Pauli PP. II promulgatus (25.01.1983), AAS 75 (1983), pars II, p. 1-317. According to the above regulation the confessor is not allowed to betray the penitent in words or in any other way and for any reason whatsoever. The violation of the seal of confession is a subject to the sanction of excommunication ex lege imposed on the priest in accordance with can. 1388, para. 1 of the 1983 Code of Canon Law. 
institution, but transfers it to the procedural inadmissibility in evidence, however, not without certain unique aspects [Wielec 2012, 93]. The below described substantive aspect will discuss criminal liability of a clergyman for violating the seal of confession and matters of denunciation as a duty. In consequence, it can be postulated that a clergyman should be treated as a person who performs the given job or performs a specific social role. In turn, the procedural aspect will refer to the inadmissibility in evidence of ${ }^{2}$ and its closer analysis will lead to crucial questions and doubts. Thus, it's necessary to indicate de lege ferenda postulates that aim to highlight that protection of the seal of confession in the Polish criminal procedure is not sufficient and changes in legislation are required.

\section{THE SUBSTANTIVE ASPECT}

In view of the doctrine, based on Art. 226 of the Criminal Code ${ }^{3}$ criminal liability of a clergyman for violating the seal of confession has been met with two different assessments. Para. 1 of the above-mentioned article states that anyone, who discloses or uses information acquired in relation to the fulfilled job position, performed work, public, economic, social or scientific activity, against provisions of an act or the duty imposed on oneself, is subject to a fine, penalty of limitation of liberty or imprisonment for up to 2 years.

Hence, the first view of the doctrine has been formed, which states that "the discussed provision of the penal code does not list religious activity or religious job position (together with public, social, economic or scientific activity), therefore applying the provision to the clergyman who violates the seal of confession would be a broad interpretation" [Kunicka-Michalska 2000 , 448]. The context in question views the above-given interpretation as not entirely justified, because a religious role is in fact a form of a social role.

The second view of the doctrine states that a clergyman can also be the perpetrator [Wróbel and Zając 2017]. "In this case, the confidentiality obligation results not only from duties imposed on the clergyman by internal regulations of the given religious community, but also from the clergyman's

${ }^{2}$ Act of 6 June 1997, the Code of Criminal Procedure, Journal of Laws of 2020, item 30 as amended [henceforth cited as: CCP], Art. 178, point 2.

${ }^{3}$ Act of 6 June 1997, the Criminal Code, Journal of Laws of 2020, item 568 as amended [henceforth cited as: CC]. 
acceptance of the obligation, which per facta concludentia results from the circumstances of confession" [ibid.]. The provision of Art. 266 CC does not directly list the seal of confession, but regards it as a kind of professional secrecy [Knoppek 2013]. The subject literature generally agrees that professional secrecy is regulated by two elements: limiting access to confidential information and prohibiting its disclosure [Rusinek 2007, 16-17]. Therefore, in order to talk about criminal liability of a clergyman for violating the seal of confession, it's necessary to indicate that he has acquired confidential information in relation to the fulfilled position or performed social activity. While analysing the premise of "fulfilling a position" by a clergyman, one can encounter a very narrow interpretation of this term, which indicates that the position is only the job position in the hierarchy of the Church [Pachnik 2011, 57-58]. One has to agree with the statement that the above view "does not have authorization and contradicts the applicable regulations of the law" [ibid.]. It seems that performing religious rites can be considered an element of the social phenomenon called religion. The religious mission carried out by a clergyman can thus be identified as a social activity [ibid.].

As a side note to the discussion, the following question is worth contemplating: Is there and what is the relation between the clergyman's confidentiality and the duty of denunciation, that is, Art. 240 CC? And: Does the duty to report crimes listed in the above-mentioned article rest with the clergyman if he has acquired them in relation to the sacrament of penance, and, when he has acquired them not only on the way of confession, but also as a direct witness to a crime, or from relations of others?

At this point it's important to refer to Art. $240 \mathrm{CC}$, which states that anyone who has credible information about a criminal preparation or an attempt or performance of a prohibited act included in the catalogue of that provision and does not immediately report it to law enforcement agencies founded to prosecute crimes is subject to imprisonment for up to 3 years. Therefore, this provision introduces a social duty to report crimes expressly listed in it, and at the same time penalises not reporting them. In answer to the above question it must be indicated that such a relation occurs and is regulated by the way in which the clergyman has come into possession of information about a crime. If he has acquired it during confession, it seems that the obligation of Art. $240 \mathrm{CC}$ is exempted in this case [KunickaMichalska 1972, 198]. The view is supported not only by legal arguments, such as the introduction of absolute inadmissibility in evidence, but also 
religious and social ones, such as freedom of religious practices or the importance of pastoral positions [ibid.].

On the other hand, when sources of information about crimes are not only confessions, but also stories of others, or when a person is a direct witness to a crime, I believe that the clergyman has a legal obligation to report the committed crime discussed in Art. 240 CC, however, views of the doctrine in this matter are not the same [Abramek 2019, 271].

\section{THE PROCEDURAL ASPECT}

The provision of Art. 178, point 2 CCP introduces a model for protecting the seal of confession in criminal procedure. According to the above a clergyman, who learnt about facts during confession mustn't be questioned as a witness. This provision introduces the absolute inadmissibility in evidence, according to which it's impossible to use an informant as the source of evidence in the indicated circumstances. Due to the absolute inadmissibility of evidence, both the penitent and the clergyman do not have the right to decide about being exempted from the obligation to keep the seal of confession. The mentioned inadmissibility of evidence is of absolute nature. Questioning the clergyman in favour of the defendant does not provide normative grounds to abolish inadmissibility of evidence.

The subjective scope of the inadmissibility regards only the clergyman. Due to a lack of the statutory definition of "a clergyman," judicial practice of the Supreme Court has to be consulted to establish the definition. According to it, a clergyman is "a person belonging to the Catholic Church or any other Church or any religious community, who can stand out from the believers of the given religion because he was appointed to continuously organize and perform religious rites." 4 The mentioned inadmissibility regards both clergymen of the Catholic Church or religious communities, which legally operate on the territory of the Republic of Poland and offer individual confessions [Tomkiewicz 2012, 51], as well as individuals who have been secularized [Rakoczy 2003, 133]. The subject literature indicates that "in order to establish the existence of inadmissibility of evidence it's

\footnotetext{
${ }^{4}$ Resolution of the Supreme Court of 16 May 1992, I KZP 1/92, OSNK 1992, No. 7-8, item 46.
} 
necessary to assume that the given religion operates legally, has grounded regulations that uniformly identify its members and is authorized to accept confessions of a confidential nature" [Kurowski 2019]. Art. 178, point 2 CCP does not list expressis verbis any other entity except clergymen, and thus it can be concluded that it is normatively permitted to question as witnesses other persons or translators familiar with the contents of confessions due to circumstances that regard the facts of those confessions.

The subjective scope of the inadmissibility covers facts obtained by a clergyman only during confession. It's correctly indicated that "provisions of Polish procedures must be regarded as broad interpretation and it must be assumed that they are related to all information disclosed and obtained during confession regardless of whether the information was given by a clergyman or a penitent. Only then the protection of the seal of confession takes on the right meaning" [Rakoczy 2003, 131].

What's most important is that inadmissibility of evidence does not protect conversations with clergymen in situations other than the sacrament of penance, legal advice or spiritual guidance [Abramek 2019, 271]. At the same time it's important to point out that Art. 178, point 2 CCP wouldn't apply in situations, in which a clergyman was a suspect or a defendant, because it applies only to clergymen who are witnesses. It's not without meaning that "the current law strictly prohibits registration of confessions in any way to respect confession and regard it as an action resulting from an internal religious need" [Wielec 2012, 273] and in the face of that the judicial body cannot use operational measures in the form of eavesdropping to find out the content of confession. At this point it's necessary to refine the statement that the introduction of inadmissibility of evidence in the case of the seal of confession is validated not only by regulations of the concordat between the Republic of Poland and the Vatican, the constitution, for instance, the applicable provision about the autonomy of Churches and religious communities, or the freedom of thought, conscience and religion, but also by the dignity of the person confessing her or his sins [Abramek 2019, 271]. 


\section{CONCLUDING REMARKS - DE LEGE FERENDA POSTULATES}

The above-outlined review of the substantive and procedural aspect allows for several concluding remarks to be formed. First and foremost, if a clergyman discloses information acquired during confession, he can be held criminally liable for this demeanour as provided for in Art. 266 CC that protects professional secrecy. Therefore, the second doctrinal view has to be regarded as correct. A clergyman, who voluntarily assumes the obligation to keep pastoral secrecy, acquires information during confession as a result of the performed pastoral position, and not as a private person [Pieron 2012, 328]. Thus, there's no doubt that the perpetrator defined in Art. 266 CC cannot be the person who didn't voluntarily assume the obligation or was obliged to do so by the provision of the act [Idem 2016, 143]. Professional secrecy does not only result from the provision of the law, professional ethics, but also the social role of the performed job. Thus, I agree with the view that if the obligation to keep professional secrecy results from professional ethics, it is an implied element of any agreement concluded to provide professional services [ibid.]. It seems correct to pose a de lege ferenda postulate to expressis verbis mention the obligation to keep the seal of confession included in Art. $266 \mathrm{CC}$, even if only to clarify certain matters.

Second of all, assuming that Art. $240 \mathrm{CC}$ applies to a clergyman if he has acquired information about the committed crime not only when performing the role of a confessor, but also from others, or as a direct witness to a crime, I reckon that it's desirable to question him during criminal proceedings, even if only to ensure that the basic purposes of the criminal proceedings have been fulfilled. Those purposes include, for instance, protection of the victim's interests [Abramek 2019, 271]. It's not difficult to conjure up a situation in which a clergyman is an eyewitness to a crime defined in Art. 240 CC, and the defendant consciously chooses him to be his or her confessor thus attempting to prevent the secret from being "revealed" [ibid.]. To sum up, protection of the victim's and the defendant's interests should be assessed ad casum and certain situations should allow questioning a clergyman. On the other hand, exempting a clergyman from the denunciation duty when the sole source of information about a crime is confession must be deemed correct as provided for, e.g., in Art. 178, point $2 \mathrm{CCP}$, which in an obvious 
way exempts the unlawfulness of behaviour defined in Art. $240 \mathrm{CC}$, which justifies that act.

Thirdly, referring to Art. 178, point $2 \mathrm{CCP}$ it must be pointed out that the legislator deems a clergyman unfit for questioning by grounding the protection of the seal of confession on objective premises. In consequence, a clergyman cannot testify in criminal proceedings even if he wants to and even if the defendant demands it.

Therefore, being unfit to be a witness is absolute. It would seem reasonable to introduce a separate provision to the Criminal Procedure Code, which would allow questioning a clergyman in relation to the facts that he has found out about during confession, but only following a mutual consent of both the clergyman and penitent. It does not change the fact that while employing the provision of Art. 180, para. CCP, the penitent's consent might be exempted only when it's beneficial to the interest of the judicial system and the facts under the seal of confession can't be established based on any other evidence. There's no doubt that it would reinforce the right of defence and the criminal and substantive situation of the defendant in situations where the clergyman's confession could influence a more lenient sentence or find the defendant innocent.

While further analysing provisions of the Criminal Procedure Code, it's important to highlight that the provision of Art. 191, para. 2 CCP does not impose any obligation on the witness questioning entity to notify the clergyman in advance about the content of Art. 178, point 2 CCP. Such a provision must be deemed negative, because bodies conducting criminal proceedings have an obligation to inform participants of proceedings about their rights and duties [Abramek 2019, 271]. Protection of the seal of confession in case of clergymen who became suspects or defendants in the course of proceedings could be ensured by introducing it to Art. 175 CCP [Szymański 2017, 84].

Fourthly, it's necessary to form a positive de lege ferenda postulate about expanding the subjective scope of Art. 178, point 2 CCP so that it includes translators and third parties, who in any way came in the possession of information disclosed during confession, in order to expand the protection of the penitent and properly respect the seal of confession [Tomkiewicz 2012, 57].

As a conclusion it can be stated that there are some legal loopholes with regard to the objective scope of inadmissibility of evidence that exempt protection of conversations with clergymen outside the sacrament of penance, legal advice and spiritual guidance [ibid., 60]. This provision 
is an explicit violation of freedom of thought, conscience and religion and requires a legislative change. The situation is similar in the case of Art. 225 , para. $3 \mathrm{CCP}$, which does not provide the same protection to documents that contain the seal of confession, but provides it only for documents connected with the performance of defensive functions. It's difficult to rationally substantiate motifs of the legislator for different types of protection of the above-mentioned secrecies. It can be concluded that their specification is similar to a certain degree, in particular when considering their presence in Art. 178 CCP [ibid., 59].

\section{REFERENCES}

Abramek, Monika. 2019. "Duchowny w procesie karnym - rozważania na kanwie zakazu dowodowego z art. 178 pkt 2 k.p.k." Monitor Prawniczy 5:271-78.

Knoppek, Krzysztof. 2013. "Komentarz do art. 261 Kodeksu postępowania cywilnego." In Kodeks postępowania cywilnego. Komentarz, vol. 1, ed. Henryk Dolecki, and Tadeusz Wiśniewski. https://sip.lex.pl/\#/commentary/587306634/147232 [accessed: 2.04.2020].

Kunicka-Michalska, Barbara. 1972. Ochrona tajemnicy zawodowej $w$ polskim prawie karnym. Warszawa: Wydwnictwo Prawnicze.

Kunicka-Michalska, Barbara. 2000. Przestepstwa przeciwko ochronie informacji niejawnych $i$ wymiarowi sprawiedliwości. Rozdziat XXX $i$ XXXIII Kodeksu karnego. Komentarz. Warszawa: Wydawnictwo C.H. Beck.

Kurowski, Michał. 2019. "Komentarz do art. 178 k.p.k." In Kodeks postępowania karnego. Część II. Komentarz aktualizowany, vol. 1, ed. Dariusz Świecki. https://sip.lex.pl/\#/ commentary/587748455/600074 [accessed: 2.04.2020].

Pachnik, Karol. 2011. "Odpowiedzialność karna duchownego przed sądem powszechnym.” Prokurator. Kwartalnik Stowarzyszenia Prokuratorów Rzeczypospolitej Polskiej 3-4:52-59.

Pieron, Bartłomiej. 2012. "Ochrona tajemnicy spowiedzi w prawie polskim." Kieleckie Studia Teologiczne 11:321-34.

Pieron, Bartłomiej. 2016. “Tajemnica zawodowa (duszpasterska) duchownego." Annales Canonici 12:131-53. http://dx.doi.org/10.15633/acan.1824

Pieróg, Michał. 2015. “Tajemnica spowiedzi świętej w prawie kanonicznym, polskim procesie cywilnym i karnym.” Studia Paradyjskie vol. 25, 169-80.

Rakoczy, Bartosz. 2003. "Tajemnica spowiedzi w polskim postępowaniu cywilnym, karnym i administracyjnym.” Przeglad Sadowy 11-12:126-38.

Rusinek, Michał. 2007. Tajemnica zawodowa i jej ochrona w polskim procesie karnym. Warszawa: Wolters Kluwer Polska.

Szymański, Michał. 2017. "Tajemnica spowiedzi w prawie polskim - stan aktualny i propozycje zmian.” Internetowy Przeglad Prawniczy TBSP UJ 4:73-85.

Tomkiewicz, Małgorzata. 2012. "Tajemnica spowiedzi i tajemnica duszpasterska w procesie karnym." Prokuratura i Prawo 2:50-64.

Wielec, Marcin. 2012. Zakaz dowodowy tajemnicy spowiedzi w postępowaniu karnym. Warszawa: Wydawnictwo Naukowe UKSW. 
Wróbel, Włodzimierz, and Dominik Zając. 2017. "Komentarz do art. 266 k.k.” In Kodeks karny. Część szczególna. Część 2. Komentarz do art. 212-277d., vol. 2, ed. Włodzimierz Wróbel, and Andrzej Zoll. https://sip.lex.pl/\#/commentary/587746548/543988 [accessed: 2.04.2020].

\section{The Seal of Confession in Polish Criminal Law - Substantive and Procedural Aspects. De lege ferenda Postulates}

\section{Summary}

This study explores the position of a minister in the context of substantive and procedural aspects of the sacramental seal in the Polish criminal law. The first issue refers to the criminal liability of the minister for disclosing of information covered by the sacramental seal of confession and the obligation of a crime notification. The second one regards an absolute inadmissibility of an evidence. In conclusion, it can be found the reference to individual aspects of the sacramental seal in the Polish criminal law and postulates de lege ferenda.

Key words: minister; criminal liability; absolute inadmissibility of an evidence; criminal law

\section{Tajemnica spowiedzi w polskim prawie karnym - aspekt materialny i proceduralny. Postulaty de lege ferenda}

\section{Streszczenie}

Artykuł analizuje pozycję duchownego w kontekście aspektu materialnego i proceduralnego polskiego prawa karnego. Pierwszy z nich odnosi się do odpowiedzialności karnej duchownego za ujawnienie informacji objętych tajemnicą spowiedzi oraz obowiązku zawiadomienia o popełnieniu przestępstwa. Z kolei drugi przedstawia bezwzględny zakaz dowodowy. W uwagach końcowych poczyniono odniesienie do zawartych w poszczególnych aspektach artykułu treści oraz postawiono postulaty de lege ferenda.

Słowa kluczowe: osoba duchowna; odpowiedzialność karna; bezwzględny zakaz dowodowy; prawo karne

Informacje o Autorze: Mgr Wioletta Dudziec-Rzeszowska - aplikant adwokacki Kujawsko-Pomorskiej Izby Adwokackiej w Toruniu; adres do korespondencji: ul. Rynek Staromiejski 17, 87-100 Torun, Polska; e-mail: dudziec.w@gmail.com; https:// orcid.org/0000-0002-3181-9073 